\title{
NEW URBAN AGENDA AND THE ISLAND BASED SETTLEMENTS DEVELOPMENT
}

\author{
Johan Silas \\ Department of Architecture, Institute of Technology Sepuluh Nopember, \\ Indonesia \\ e-mail: mukimits@yahoo.com
}

\begin{abstract}
World population entered the first two decades of the XXI Century did not meet the grand expectation of a prosperous and just world as poverty and all it's consequences are still widely visible in fast growing cities. As the more people are now living in urban areas, in towns and cities, obviously their future depend on the social justice, healthy economic growth and quality environment. In the Habitat III meeting in Quito Ecuador (10-2016), they endorsed and agreed on a new agenda for meeting the challenges faced by the world in term of (urban) place where people can actualised themselves in meeting the new opportunities and changes offered in the course of time. The result of this research is that Indonesia needs to further adopt and adapt the New Urban Agenda to meet the unique need and situation of Indonesia in the future which can only be done by native experts (Indonesia) as experience and interest should rest on the shoulder of Indonesian.
\end{abstract}

Keywords: prosperous, towns and cities, new urban agenda

\section{INTRODUCTION}

When world population entered the first two decades of the XXI Century, it did not meet the grand Expectation of a prosperous and just world as poverty and all it's consequences are still widely visible in fast growing cities. There is a need for certain major issues to be addressed such as:

1. World's financial crisis of 2007/2008 that also proved the geo-politics and geoeconomics set-up have shifted from the West to the East and gradually dominated by major fast growing countries such as China, India and Indonesia that command resource and market.

2. Indonesia as a unique and only country among to the three emerging big countries due to it's archipelago configuration and therefore need its own model for development and no historical experience exist as reference to draft the model to serve the need of people living in over 17,300 islands connecting oceans and continents. 
3. For a long time, development model has always been referred to land based knowledge derived from Western countries that has limited geographic experience in dealing with (thousand) islands based model.

4. Urban development in Indonesia has a dual model implemented as land based for larger islands and island based for smaller islands.

5. "Urbanization is not about building the cities' infrastructures services, but improve people's livelihood problems"

\section{THEORY / RESEARCH METHODS}

As the more people are now living in urban areas, in towns and cities, obviously their future depend on the social justice, healthy economic growth and quality environment. For this development will ensure economic growth with result that "True development is about people, not of things or richness". Are The People there when development in happening? China has taken bold and radical actions in making their Urban Dream come true by among others implementing urbanization at an unprecedented rate such as bringing real urban development to the villages rather than letting people leaving their farm and land by going to the cities. This deliver the following result:

1. Between 1978 and 2012, the fraction of the nation's population dwelling in cities increased from $17.9 \%$ to $52.6 \%$.

2. These are still uncharted waters, but China has a plan. Government released the National New-type Urbanization Plan, which sets targets for China's urban population to rise $1 \%$ a year to reach $60 \%$ by 2020 .

3. The plan is comprehensive and ambitious. It covers every conceivable aspect of urbanization, from rural-urban migration and integration to the spatial distribution of and linkages between cities; sustainable development; institutional re-arrangements; and implementation. Some result of the plan can be seen in the following figures.
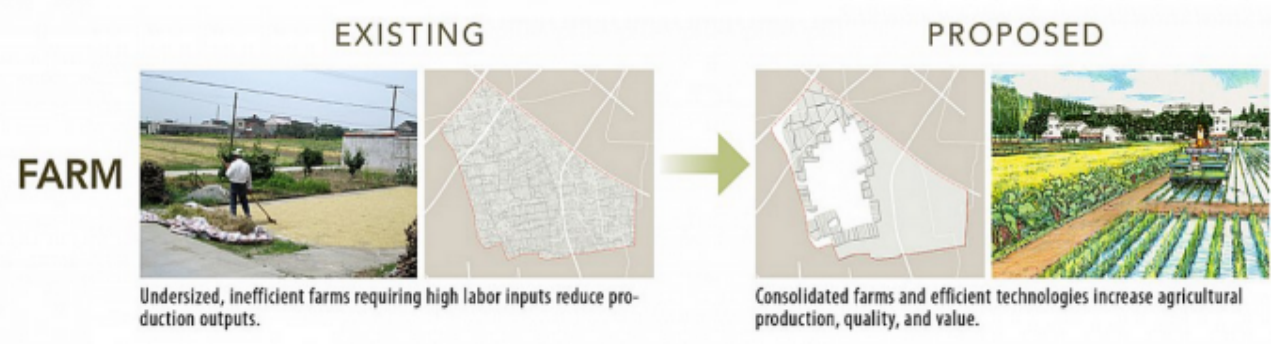

Figure 1. The Existing and the Proposed of Farm Area 


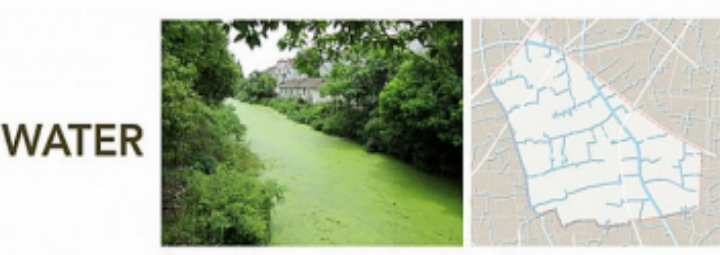

Dead-end, disconnected canals result in polluted waterways.

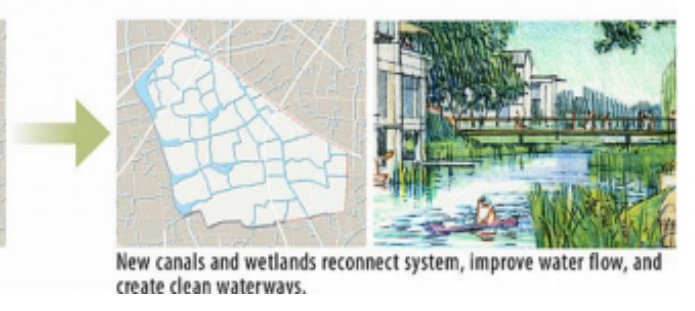

Figure 2. The existing and the proposed of water area

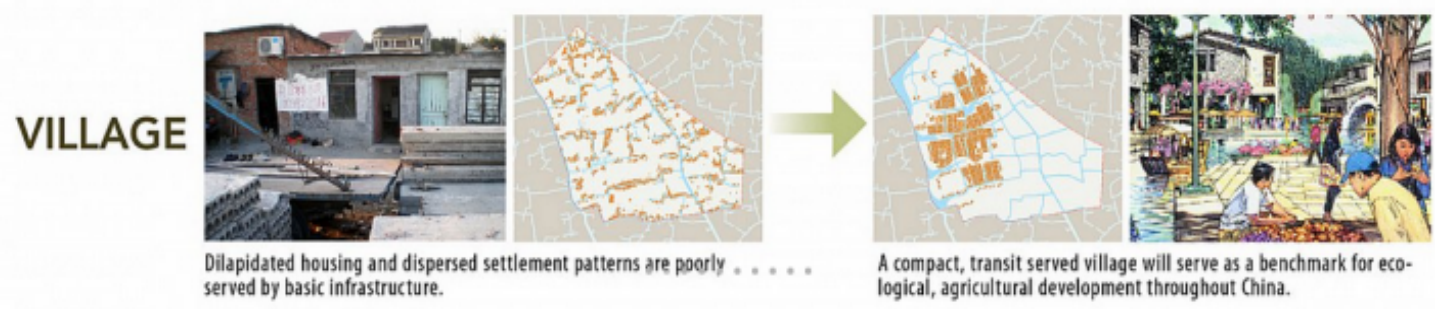

Figure 3. The Existing and the Proposed of Village Area

\section{RESULTS AND DISCUSSION}

\section{Human Resource Development vs Physical Development}

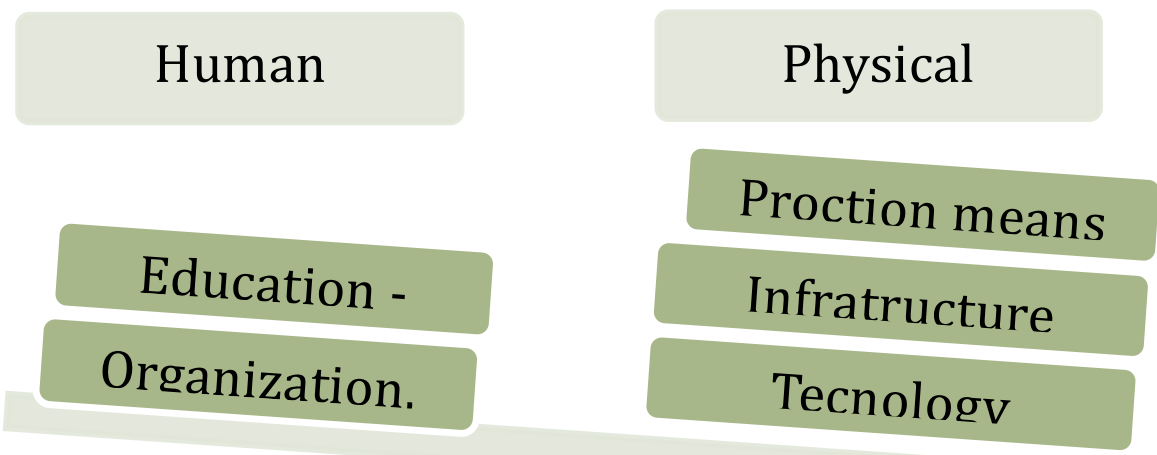

Figure 4. Human Resource Development vs Physical Development 
As can be seen in the map below, the National Planning Board (Bappenes) in 2014 started drafting the vision of Indonesia towns and cities in the year 2014 (when Indonesia is celebrating it's centennial independence) as a free and democratic country, urban development will still be concentrated in the islands of Jawa and Sumatera.

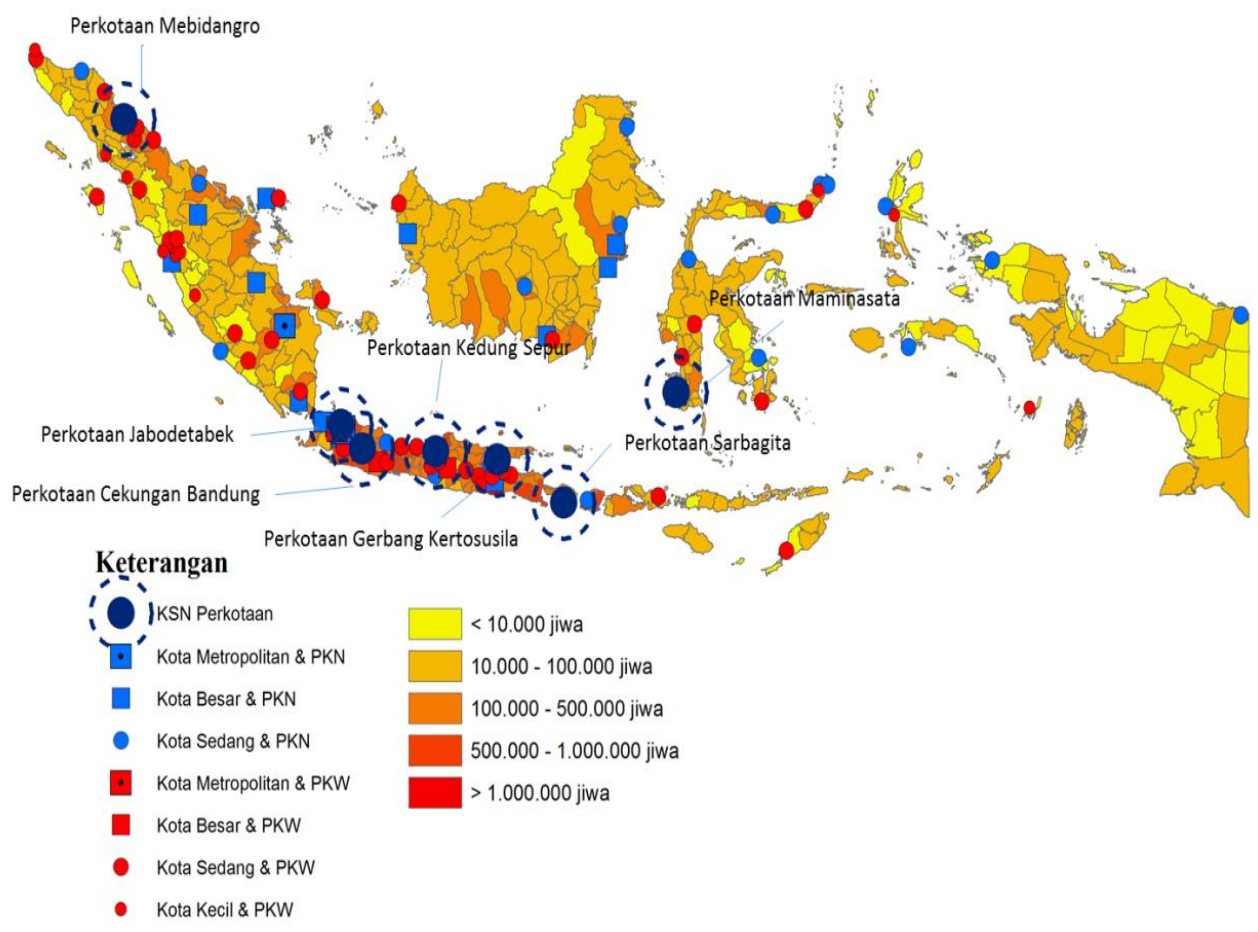

Figure 5. Cities Distribution in Indonesia

As we can see from the map prepared by Bappenes (2014) above, development of large cities only happened in the islands of Java and Sumatera. It does not really serve the people of Indonesia as a whole. Therefore the remaining time and using NUA as guide, urbanization should equitably reach all part of the country based on towns that is the hub of many islands especially in the eastern part of the country so that by 2045 urbanization serve all Indonesia.

In the Habitat III meeting in Quito Ecuador (10-2016), they endorsed and agreed on a new agenda for meeting the challenges faced by the world in term of (urban) place where people can actualised themselves in meeting the new opportunities and changes offered in the course of time. The New Urban Agenda (NUA) that was adopted in the Quito summit approved the new urban and settlements among others:

1. Fulfill their social function, including the social and ecological function of land, with a view to progressively achieve the full realization of the right to adequate housing, as a component of the right to an adequate standard of living, without discrimination in any kind, universal access to safe and affordable drinking water 
and sanitation, as well as equal access for all to public goods and quality services in areas such as food security and nutrition, health, education, infrastructure, transportation and mobility, energy, air quality, and livelihoods;

2. Participatory, promote civic engagement, engender a sense of belonging and ownership among all their inhabitants, prioritize safe, inclusive, accessible, green, and quality public spaces, friendly for families, enhance social and intergenerational interactions, cultural expressions, and political participation, as appropriate, and foster social cohesion, inclusion, and safety in peaceful and pluralistic societies, where the needs of all inhabitants are met, recognizing the specific needs of those in vulnerable situations;

3. Achieve gender equality and empower all women and girls, ensuring women's full and effective participation and equal rights in all fields and in leadership at all levels of decision-making, and by ensuring decent work and equal pay for equal work, or work of equal value for all women, as well as preventing and eliminating all forms of discrimination, violence, and harassment against women and girls in private and public spaces;

4. Meet the challenges and opportunities of present and future sustained, inclusive, and sustainable economic growth, leveraging urbanization for structural transformation, high productivity, value- added activities, and resource efficiency, harnessing local economies, taking note of the contribution of the informal economy while supporting a sustainable transition to the formal economy;

5. Fulfill their territorial functions across administrative boundaries, and act as hubs and drivers for balanced sustainable and integrated urban and territorial development at all levels;

6. Promote age- and gender-responsive planning and investment for sustainable, safe, and accessible urban mobility for all and resource efficient transport systems for passengers and freight, effectively linking people, places, goods, services, and economic opportunities;

7. Adopt and implement disaster risk reduction and management, reduce vulnerability, build resilience and responsiveness to natural and man-made hazards, and foster mitigation and adaptation to climate change;

8. Protect, conserve, restore, and promote their ecosystems, water, natural habitats, and biodiversity, minimize their environmental impact, and change to sustainable consumption and production patterns.

The question now is in what position are the existing towns and cities in Indonesia against the NUA? What will be the impact of NUA to island based towns and cities that are largely spread throughout Indonesia? In short many towns and cities by tradition to some extent has met many NUA objectives. The relation and impact of the vision to present Indonesia settlements can be explained as follows:

1. People Cantered, not only is importance, but people themselves need to improve what they can and will do for themselves. The achievement is due to the fact that almost all settlements here, were self-built by the inhabitants. 
2. Surabaya is home to a mix and plural society. Every citizen has their own space in the city and deliver what they wanted to be, no restrictions and constrain in any form what-so-ever were delivered.

3. Land is most crucial to urban development, but land is also the last resort of wealth to many ordinary people. In easing the access to land it should be ensured that land would be managed for the people with possibility for the capital to be included.

4. Surabaya was the first city ever in the implementation of the kampoeng verbetering programme (1924), the colonial era model of KIP. In late sixties, Jakarta and Surabaya re-introduced the KIP based on a comprehensive concept and Surabaya also consistently improved the concept from the simple provision of infrastructure model, to the comprehensive community organisation model and alleviating the kampung economy from the subsistent level to reach city wide market and beyond.

5. The Vision of Surabaya and many other cities and towns to be a world city is not and will never be in quantitative term only, but the qualitative aspects are prominent and taken seriously in its implementation.

6. Surabaya and other cities believe that the middle class economy is extremely important, growing fast in term of quality and quantity and effective in making it better. Macro economy is facilitated, the messo economy or consumer economy is supported and the micro economy improved that will sooner be part of the urban economy as a whole.

7. Surabaya and some other cities has been offered to built cross city toll road and to include the bus-way as support. However, Surabaya reject the idea and instead opted to build new road service and widen the existing main arterial road to ease the congestion condition. But also Surabaya introduced the green urban transport as a strategic move for future need by constructing the tramway and LRT.

8. Finally, Surabaya and many cities and towns have been performing the walking and learning experience from local governments, students of many levels of education, to community group to be in the field and received the needed information from the real stakeholders.

What about the issue of Island Based Settlements Development needed to deal with archipelago geographical configuration of Indonesia consist of more than 17.000 islands that also needs to be part of urbanization issue? Island based development consist of three major elements:

1. Human Settlements,

2. Strengthening Local Economy, and

3. Development of Human Resources

Human Resource Development is the Key Capital for the overall urban development (urbanizing) and small towns on many islands in particular that also function as interface between towns/cities and the rural area (fishing villages and the agriculture villages). Sustainability of island-based economy depends on place (settlement) and people as the prime mover. Main activities will be placed at high schools to prepare the need for future people power. Government has to develop 
sustainable linkage from small towns in islands to cities in the larger island, in tangible (physical) as well as intangible (virtual) terms comprehensively

As mentioned earlier, there exist hardly any reference of the island based human settlements development experience that is needed to be use to deal and plan the issue human settlements development in remote islands. It is therefore not a surprise that NUA hardly mentioned the issue of the need of people living on islands that has to depend on its own ingenuously in building their habitat. To some extent local wisdom and working experience do exist and has not been sufficiently studied and therefore also not properly developed. After the NUA, Indonesian experts have to rely on its own resource to capture the wisdom of people that managed to survive in living on islands that have been there for generations and always over looked. Exiting knowledge and instrument of ICT can resolve the problem sooner with a longer future perspective.

\section{CONCLUSIONS}

Needless to say that for Indonesia hard work ahead is needed to further adopt and adapt the NUA to meet the unique need and situation of Indonesia in the future. And it can only be done by native experts (Indonesia) as experience and interest should rest on the shoulder of Indonesian themselves especially its experts and inperts on the issue of habitat and bear the responsibility not only to the present generation, but most importantly for their own children and grand children that will asked what has my parents and grand parents done to prepare for my future need. A quick and positive actions need to be taken not now but yesterday as the clock of progress has already been ticking before it is over due.

\section{REFERENCES}

UN Habitat (2016), the New Urban Agenda, Quito.

Bappenas (2015), Kebijakan Nasional Pembangunan Perkotaan, Bappenas, Jakarta. Kementerian Koordinator Bidang Perekonomian (2014), Laporan Tahunan, Menko Perekonomian, Jakarta.

Kementerian Koordinator Bidang Perekonomian dan Laboratorium Perumahan dan

Permukiman (2015), Pembangunan Perkotaan Strategis menuju Perkotaan Indonesia yang berkeadilan-berkelanjutan.

Silas, J. (1996), Kampung Surabaya menuju Metropolitan. Bappeko, Surabaya. Pemerintah Kota Surabaya (2015), Kampung Surabaya Menuju Abad XXI. 
Silas: NEW URBAN AGENDA AND THE ISLAND BASED SETTLEMENTS DEVELOPMENT

This page is intentionally left blank 